\title{
PENGARUH KOMPETENSI SUMBER DAYA MANUSIA, PEMANFAATAN TEKNOLOGI INFORMASI, PENGAWASAN KEUANGAN DAERAH, DAN PENGENDALIAN INTERN TERHADAP KUALITAS LAPORAN KEUANGAN PADA OPD KABUPATEN SUMENEP
}

\author{
Ucik Aisyah Putri $^{1}$, Hafidhah ${ }^{2}$, Imam Darul Firmansyah ${ }^{3}$ \\ ${ }^{1,2,3)}$ Fakultas Ekonomi dan Bisnis Universitas Wiraraja \\ Email: ${ }^{1}$ ucik.aisyah@gmail.com, ${ }^{2}$ hafidhah@wiraraja.ac.id, ${ }^{3}$ darul.faradis@gmail.com
}

\begin{abstract}
ABSTRAK
Kabupaten Sumenep merupakan salah satu pemerintah daerah hingga tahun 2016 laporan audit atas laporan keuangan masih memperoleh opini wajar dengan pengecualian. Hal tersebut terjadi dikarenakan masih adanya kebuntuan administrasi yang disebabkan adanya kejanggalan yang dilakukan oleh beberapa OPD Kabupaten Sumenep. Jika dilihat dari opini atas hasil pemeriksaan laporan keuangan yang didapat oleh pemerintah Kabupaten Sumenep belum bisa menjadi yang terbaik, Karena laporan keuangan yang berkualitas merupakan laporan keuangan yang memenuhi karakteristik kualitatif dan mendapatkan hasil opini wajar tanpa pengecualian.

Jenis penelitian ini adalah penelitian kuantitatif, sampel dalam penelitian ini terdapat 66 responden dengan teknik pengambilan sampel menggunakan porpusive sampling dengan kriteria pusat pertanggung jawaban sektor publik dan fungsi pengawasan keuangan. Metode pengumpulan data melalui kuesioner yang disebarkan pada 22 OPD Kabupaten Sumenep.

Hasil penelitian ini menunjukkan bahwa kompetensi sumber daya manusia tidak berpengaruh terhadap kualitas laporan keuangan dengan nilia signifikan 0,057 >0,05, pemanfaatan teknologi informasi tidak berpengaruh terhadap kualitas laporan keuangan dengan nilai signifikan $0,131>0,05$, pengawasan keuangan daerah berpengaruh terhadap kualitas laporan keuangan dengan nilai signifkan $0.006<0,05$, dan pengendalian intern berpengaruh terhadap kualitas laporan keuangan dengan nilai signifikan $0,000<0,05$. kompetensi sumber daya manusia, pemanfaatan teknologi informasi, pengawasan keuangan daerah, dan pengendalian intern berpengaruh secara simultan terhadap kualitas laporan keuangan daerah dengan nilai signifikan $0,000<0,05$.
\end{abstract}

Kata Kunci: Kompetensi, teknologi informasi, pengendalian intern, laporan keuangan.

\section{INTRODUCTION}

Di Indonesia dalam mengkaji pelaporan keuangan pemerintah adalah suatu hal yang sangat menarik, dikarenakan tuntutan terhadap akuntabilitas lembaga publik semakin menguat baik dipusat maupun didaerah. Semakin besar tuntutan terhadap akuntabilitas publik maka akan menimbulkan sebuah implikasi bagi pihak manajemen pemerintahan dalam memberikan sebuah informasi yang lebih baik terhadap publik.
Undang-Undang No. 17 Tahun 2003 tentang keuangan Negara dan Undang-Undang No. 32 Tahun 2004 tentang pemerintahan daerah yang mengatur tentang pertanggung jawaban dalam penyelenggaraan pemerintahan. Laporan pertanggung jawaban disampaikan dengan mewujudkan transparansi dan akuntabilitas pengelolaan keuangan pemerintah yang berbentuk sebuah Laporan Keuangan Pemerintah Daerah (LKPD). 
Dalam menyajikan laporan keuangan, pemerintah daerah harus dapat menyajikan dengan memuat informasi keuangan yang berkualitas. Laporan keuangan yang berkualitas atau ideal adalah laporan keuangan yang memenuhi karakteristik kualitatif dan dapat dipertanggungjawabkan, karena hasil dari laporan keuangan akan dimanfaatkan untuk seluruh entitas sebagai pedoman dalam membuat kebijakan dan keputusan penyelenggaraan pemerintahan. Pada Peraturan Pemerintah No.71 Tahun 2010 yang membahas tentang kerangka konseptual akuntansi pemerintah yang berisi karakteristik kualitatif keuangan pemerintah yang meliputi relevan, andal, dapat dibandingkan, dan dapat dipahami. Jika keempat karakteristik tersebut terpenuhi dalam informasi laporan keuangan, maka pemerintah daerah telah mampu mewujudkan transparansi dan akuntabilitas dalam pelaporan keuangannya.

Lembaga pemerintah yang wajib membuat laporan keuangan daerah salah satunya yaitu Organisasi Perangkat Daerah (OPD). OPD merupakan suatu lembaga pemerintah yang melaksanakan fungsi eksekutif yang bekerjasama dalam menjalankan penyelenggaraan pemerintah agar berjalan secara maksimal, sehingga laporan keuangan wajib disusun oleh setiap OPD. Setiap tahun penyusunan laporan keuangan yang dihasilkan oleh OPD diperiksa Badan Pemeriksa Keuangan (BPK) dengan memberikan opini, apabila opini yang diberikan terhadap laporan keuangan daerah berupa wajar tanpa pengecualian, berarti laporan keuangan tersebut dapat dikatakan wajar dan berkualitas.

Motivasi dalam penelitian ini dilakukan karena pemerintah Kabupaten Sumenep merupakan salah satu pemerintah daerah yang hingga tahun 2016 laporan audit atas laporan keungan masih belum bisa memperoleh opini WTP. Pemerintah Kabupaten Sumenep atas hasil laporan audit masih bertahan dengan opini WDP yang diperolehnya untuk 5 tahun terakhir. Salah satu penyebab belum diraihnya opini wajar tanpa pengecualian oleh pemerintah Kabupaten Sumenep dari BPK yaitu karena sistem pengelolaan keuangan daerah yang belum optimal. Fakta lain yang menyebabkan pemerintah Kabupaten Sumenep masih bertahan dengan opini WDP ditahun 2016 yaitu adanya sebuah kebuntuan dalam administrasi. BPK masih banyak menemukan kejanggalan pada pengelolaan dan penggunaan keuangan daerah pada sejumlah organisasi perangkat daerah dipemerintah Kabupaten Sumenep. BPK merekomendasikan agar pemerintah Kabupaten Sumenep mengembalikan uang negara sebesar Rp. 6,8 miliar ke kas daerah. Hal tersebut terjadi dikarenakan masih terdapat beberapa kegiatan realisasi pengadaan barang dan jasa yang tidak dapat didukung dengan bukti pertanggung jawaban yang sah atau valid. Temuan kejanggalan pelaksanaan tersebut tersebar hampir di semua OPD lingkungan pemerintah Kabupaten Sumenep dengan jumlah uang yang harus dikembalikan variatif.

Hal ini terjadi disebabkan masih lemahnya kemampuan sumber daya manusia dan pengendalian internal organisasi pemerintahan pada saat ini. Lemahnya kemampuan sumber daya manusia tersebut tidak hanya diakibatkan oleh kelemahan pengelolaan keuangan daerah sektor administrasi dan birokrasi namun juga bukan hanya akibat keterbatasan dukungan sumber daya manusia saja, akan tetapi juga ada akibat 
dari kelemahan law enforcement. Law enforcement yaitu kepatuhan terhadap peraturan, aturan, prosedur serta perencanaan yang telah ditetapkan sebelumnya oleh pemerintah termasuk laporan keuangan yang dihasilkan. Penyajian transaksi dan laporan keuangan harus jujur agar informasi yang dihasilkan tidak hanya dapat dipahami dan dimengerti oleh pemakai, namun juga dapat dipercaya dan bermanfaat untuk pemakai itu sendiri. Selain itu, faktor yang berpengaruh terhadap hasil pengelolaan keuangan yang wajar, akurat, dan berkualitas yaitu lemahnya pengawasan keuangan daerah yang disebabkan kurangnya tenaga kepengawasan dari lembaga pengawas untuk setiap instansi pemerintah, sehingga kepengawasan terhadap setiap instansi pemerintah kurang maksimal. Selain itu, dilihat dari segi pemanfaatan teknologi informasi masih terdapat kendala terkait dengan perangkat-perangkat komputer yang dipakai, selain itu dilihat dari segi sumber daya manusianya masih kurang dalam memanfaatkan teknologi informasi yang tersedia. Dalam menghasilkan laporan keuangan daerah yang berkualitas dan andal perlu adanya sebuah kualitas sumber daya manusia yang bagus serta adanya suatu pemanfaatan teknologi informasi yang tepat. Selain itu juga keefektifan dan keefisienan pengawasan keuangan daerah serta pengendalian internal juga sangat diperlukan guna pencapaian hasil yang maksimal sehingga dapat mempengaruhi hasil opini laporan keuangan yang akan diaudit oleh BPK nantinya.

\section{LITERATURE REVIEW}

\section{Kompetensi Sumber Daya Manusia}

Menurut Peraturan Menteri Dalam Negeri Republik Indonesia tahun 2013 pasal 1 tentang kompetensi, kompetensi merupakan suatu kemampuan dan karakteristik yang dimiliki oleh seorang pegawai negeri sipil yang berupa pengetahuan, keterampilan, dan sikap perilaku yang diperlukan dalam pelaksanaan tugas jabatannya, sehingga para pegawai negeri sipil dapat melaksanakan tugasnya secara profesional, efektif dan efisien.

Menurut Moeheriono (2012: 14) terdapat beberapa karakteristik kompetensi dasar dalam setiap individu yang terdiri dari:

a. Watak yaitu bagaimana seseorang merespon sesuatu dengan sebuah cara tertentu atau yang membuat seseorang memiliki sikap atau perilaku.

b. Motif yaitu sesuatu yang diinginkan seseorang yang mengakibatkan yang bersangkutan untuk melakukan suatu tindakan.

c. Bawaan yaitu sikap dan nilai yang dimiliki seseorang.

d. Pengetahuan informasi yang dimiliki seseorang pada bidang tertentu.

e. Keterampilan atau keahlian yaitu kemampuan untuk melakukan tugas tertentu baik secara fisik maupun mental.

\section{Pemanfaatan Teknologi Informasi}

Dalam mengembangkan dan memanfaatkan teknologi informasi pemerintah daerah wajib untuk meningkatkan kemampuan untuk mengelola keuangan daerah dan menyalurkan informasi keuangan kepada pelayanan publik. Selain itu, dengan adanya pembuatan situs website pemerintahan dapat memudahkan masyarakat luas untuk mengetahui informasi mengenai pemerintahan seperti kinerja, program maupun kebijakan baru yang berkaitan dengan instansi pemerintahan (Putri, 2017).

Menurut Peraturan Pemerintah Nomor 56 Tahun 2005 tentang Sistem Informasi 
Keuangan Daerah merupakan pengganti dari Peraturan Pemerintah Nomor 11 Tahun 2001 tentang informasi keuangan pemerintah mengatur tentang kewajiban pemanfaatan teknologi informasi pemerintah pusat dan pemerintah daerah. Adanya teknologi informasi diharapkan dapat membantu dalam proses pengelolaan laporan keuangan pemerintah daerah sehingga dapat menghasilkan keuangan yang tepat waktu dan andal serta dapat lebih efektif dan efisien dibandingkan dengan secara manual.

\section{Pengawasan Keuangan Daerah}

Pengawasan dalam penyelenggaraan pemerintah daerah menurut Peraturan Pemerintah No. 79 tahun 2005 pasal 1 ayat (4) dan Peraturan Pemerintah No. 23 tahun 2007 pasal 1 ayat (1) menyatakan bahwa pengawasan atas penyelenggaran pemerintahan daerah merupakan proses kegiatan yang ditujukan untuk menjamin agar pemerintahan daerah berjalan secara efisien dan efektif sesuai dengan rencana dan ketentuan peraturan perundang-undangan. Pengawasan pada dasarnya diarahkan sepenuhnya untuk menghindari adanya penyelewengan atau penyimpangan dalam tujuan yang akan dicapai.

Menurut Riawan (2006: 138) Hal-hal yang meliputi ruang lingkup pengawasan yaitu:

1. Pengawasan internal yaitu pengawasan yang dilakukan oleh seseorang yang jabatannya secara langsung melaksanakan tugas pengawasan atas penyelenggaraan pemerintah daerah atas nama Menteri Dalam Negeri atau Kepala Daerah yang dilakukan oleh Inspektorat Provinsi Kabupaten atau Kota.

2. Pengawasan eksternal yaitu pengawasan yang dilakukan oleh lembaga yang berada diluar lembaga eksekutif. Misal BPK yang mengawasi atau memeriksa secara langsung laporan keuangan secara lengkap.

\section{Pengendalian Intern}

Menurut Gusti (2008: 283) menyatakan bahwa sistem pengendalian intern merupakan prosedur dan kebijakan yang dirancang dalam memberikan keyakinan yang memadai bagi pihak manajemen dalam mencapai tujuan dan sasaran bagi sebuah organisasi.

Peraturan Pemerintah No. 60 Tahun 2008 menyatakan bahwa unsur sistem pengendalian intern dalam peraturan pemerintah mengacu pada unsur sistem pengendalian intern yang telah dipraktikan didalam lingkungan pemerintah di berbagai Negara, yang meliputi; Lingkungan Pengendalian, Penilaian Resiko, Kegiatan Pengendalian, Komunikasi dan Informasi, dan Pemantauan

\section{Kualitas Laporan Keuangan}

Menurut Jumingan (2009: 4) laporan keuangan adalah hasil akhir tindakan pembuatan ringkasan data kuangan suatu instansi. Laporan keuangan disusun untuk kepentingan manajemen dan pihak yang mempunyai kepetingan dengan data keuangan suatu instansi.

Sesuai Peraturan Pemerintah No. 71 tahun 2010 laporan keuangan dapat dikatakan berkualitas jika sudah memenuhi syarat karakteristik kualitatif yaitu: (1) Relevan, (2) Andal, (3) Dapat Dibandngkan, dan (4) Dapat Dipahami.

\section{METHODS}

Pada penelitian ini jenis penilitian yang digunakan merupakan jenis penelitian kuantitatif. Populasi pada penelitian ini yaitu 
OPD di Kabupaten Sumenep dengan jumlah sebanyak 30 OPD. Sampel dalam penelitian ini menggunakan teknik pengambilan sampel yaitu porpusive sampling berdasarakan pusat pertanggung jawaban sektor publik dan fungsi pengawasan keuangan yang berjumlah sebanyak 22 OPD yang terdiri dari pusat biaya, pusat pendapatan, pusat laba, pusat investasi, fungsi pengawas laporan keuangan. Pada penelitian ini pengambilan responden mencakup kepala subbagian keuangan, dan 2 staf subbagian keuangan, sehingga dalam setiap OPD diambil sebanyak 3 orang yang akan menjadi responden, maka pengambilan sampel pada penelitian ini $22 \times 3=66$ sehingga yang menjadi responden sebanyak 66 responden.

Jenis data dalam penelitian ini adalah jenis data kuantitatif. Sumber data pada penelitian ini merupakan data primer yang berupa angket baku. Teknik pengumpulan data dalam penelitian ini yang digunakan oleh penulis dengan cara memberikan angket baku kepada kepala bagian keuangan dan staf bagian keuangan OPD di wilayah Kabupaten Sumenep. Angket baku secara langsung diantarkan ke OPD diwilayah Kabupaten Sumenep. Setelah itu, pengumpulan kembali kuesioner dengan menjemputnya secara langsung ke OPD yang ada di Kabupaten Sumenep.

\section{RESULTS AND DISCUSSIONS}

\section{Uji Validitas}

Berdasarkan hasil pengujian semua variabel bebas dan variabel terikat menunjukkan bahwa seluruh data yang diperoleh adalah valid. Hal tersebut dapat dilihat dari nilai Corrected Item-Total Correlation yang lebih besar dari r-tabel.

\section{Uji Reliabilitas}

Tabel 1

Uji Reliabilitas

\begin{tabular}{|l|c|}
\hline Variabel & $\begin{array}{c}\text { Cronbach's Alpha if } \\
\text { Item Deleted }\end{array}$ \\
\hline $\mathrm{X}_{1}$ & 0.883 \\
\hline $\mathrm{X}_{2}$ & 0.765 \\
\hline $\mathrm{X} 3$ & 0.798 \\
\hline $\mathrm{X} 4$ & 0.839 \\
\hline $\mathrm{Y}$ & 0.854 \\
\hline
\end{tabular}

Berdasarkan tabel 1 di atas dapat dikatakan variabel dari instrumen pernyataan yang digunakan dalam penelitian ini sudah reliabel dengan nilai signifika diata 0,06 .

\section{Uji Multikolinearitas}

\section{Tabel 2}

Uji multikolinearitas

\begin{tabular}{|c|c|}
\hline Model & $\begin{array}{c}\text { Collinearity } \\
\text { Statistics }\end{array}$ \\
\cline { 2 - 2 } (X1) & Tolerance \\
\hline X2) & 0.779 \\
(X3) & 0.683 \\
(X4) & 0.627 \\
& 0.429 \\
\hline
\end{tabular}

Berdasarkan tabel 2 diatas bahwa nilai tolerance untuk semua variabel bebas lebih besar dari 0.10 sehingga tidak terjadi multikolinearitas.

\section{Uji Heteroskedastisitas}

\section{Tabel 3}

Uji Heteroskedastisitas

\begin{tabular}{|c|c|c|}
\hline Model & T & Sig \\
\hline X1 & -.382 & 0.704 \\
\hline X2 & -.479 & 0.633 \\
\hline X3 & -.268 & 0.789 \\
\hline $\mathbf{X 4}$ & 1.404 & 0.165 \\
\hline
\end{tabular}

Berdasarkan tabel 3 dari hasil pengujian gletser menunjukkan bahwa seluruh variabel 
bebas memiliki nilai signifikan diatas 0,05 sehingga tidak terjadi heteroskedastisitas.

Uji Autokorelasi

Tabel 4

Uji Autokorelasi

\begin{tabular}{|c|c|c|}
\hline Model & $\begin{array}{c}\text { Std. Error } \\
\text { Of the } \\
\text { Estimate }\end{array}$ & $\begin{array}{c}\text { Durbin } \\
\text { Watson }\end{array}$ \\
\hline $\mathbf{1}$ & 3.089 & 2.112 \\
\hline
\end{tabular}

Berdasarkan tabel 4, diketahui nilai DW 2,112 untuk $\mathrm{N}=66$ dan jumlah variabel bebas $4(\mathrm{k}=4)$ maka diperoleh nilai $\mathrm{du}=1.7319$ dan $\mathrm{dl}=1.4758 . \quad \mathrm{du}<\mathrm{dw}<4-\mathrm{du}(1.7319<$ $2,112<2,2681)$, sehingga data dalam penelitian ini tidak terjadi autokorelasi.

\section{Uji Normalitas}

Tabel 5

Uji Normalitas

\begin{tabular}{|c|c|}
\hline & $\begin{array}{c}\text { Unstandardized } \\
\text { residual }\end{array}$ \\
\hline $\mathrm{N}$ & 66 \\
Asymp, & .200 \\
$\begin{array}{c}\text { Sig. (2- } \\
\text { tailed) }\end{array}$ & \\
\hline
\end{tabular}

Berdasarkan tabel 6 uji Kolmogrov Smirnov diatas bahwa nilai signifikan sebesar 0,200 > 0,05 sehingga data tersebut berdistribusi normal.

\section{Uji T}

\section{Tabel 6}

Uji T

\begin{tabular}{|c|c|c|c|}
\hline Model & $\begin{array}{c}\text { Standardized } \\
\text { Coefficients }\end{array}$ & T & Sig. \\
\cline { 2 - 2 } & Beta & & \\
\hline & & & \\
X1 & 0.176 & 1.943 & 0.057 \\
$\mathbf{X 2}$ & -0.148 & -1.532 & 0.131 \\
$\mathbf{X 3}$ & 0.286 & 2.829 & 0.006
\end{tabular}

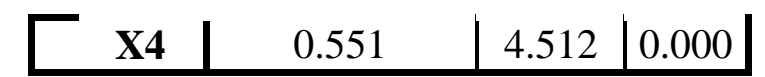

Berdasarkan tabel 6 di atas bahwa X1 dan X2 memiliki nilai signifikan di atas 0,05 yang berarti tidak mempunyai pengaruh terhadap variabel $\mathrm{Y}$, sedangkan variabel $\mathrm{X} 3$ dan $\mathrm{X} 4$ memiliki nilai signifikan dibawah 0,05 yang berarti memiliki pengaruh terhadap variabel Y.

\section{Uji F}

Tabel 7

Uji F

\begin{tabular}{|c|c|c|}
\hline \multicolumn{3}{|c|}{ Uji F } \\
\hline Model & $\mathbf{F}$ & Sig. \\
\hline $\begin{array}{cc} & \text { Regression } \\
1 & \text { Residual } \\
& \text { Total } \\
\end{array}$ & 23.827 & $.000 \mathrm{~b}$ \\
\hline
\end{tabular}

Berdasarkan tabel 7 di atas memiliki nilai siginifikan dibawah 0,05 yang berarti semua variabel bebas memiliki pengaruh secara simultan terhadap variabel Y.

Uji Koefisien Determinasi

Tabel 8

Uji Koefisien Determinasi

\begin{tabular}{|c|c|c|c|c|}
\hline Model & $\mathbf{R}$ & $\begin{array}{c}\mathbf{R} \\
\text { Square }\end{array}$ & $\begin{array}{c}\text { Adjusted } \\
\text { R Square }\end{array}$ & $\begin{array}{c}\text { Std. Error } \\
\text { of the } \\
\text { Estimate }\end{array}$ \\
\hline 1 & $.781 \mathrm{a}$ & .610 & .584 & 3.089 \\
\hline
\end{tabular}

Berdasarkan tabel 8 di atas terlihat bahwa nilai Adjusted $R$ Square 0,584 yang berrati bahwa kemampuan variabel bebas sebesar $58,4 \%$ dalam menjelaskan variabel terikat. 


\section{DISCUSSION}

\section{Pengaruh Kompetensi Sumber Daya Manusia Terhadap Kualitas Laporan Keuangan}

Berdasarkan hasil analisis data yang dilakukan secara parsial menunjukkan bahwa kompetensi sumber daya manusia tidak memiliki pengaruh yang signifikan terhadap kualitas laporan keuangan daerah pada OPD Kabupaten Sumenep. Hal ini berarti bahwa pegawai yang tidak berkompeten atau berkompeten tidak mempengaruhi terhadap kualitas laporan keuangan, karena laporan keuangan tersebut dibuat sesuai dengan standart yang dibuat oleh pemerintah dan menggunakan software yang sama. Pegawai yang mengelola laporan keuangan sebelum melakukan pengelolaan laporan keuangan diberikan sebuah pelatihan mengenai cara mengelola laporan keuangan sesuai standart yang berlaku. Dengan demikian dapat diartikan bahwa pegawai yang berkompeten ataupun tidak berkompeten dianggap memiliki kompetensi sumber daya manusia yang sama dalam mengelola laporan keuangan, sehingga tidak mempengaruhi terhadap kualitas laporan keuangan. Hasil penelitian ini sejalan dengan penelitian yang dilakukan oleh Ratna Wijayanti dan Nur Handayani (2017) yang menyatakan bahwa kompetensi sumber daya manusia tidak memiliki pengaruh terhadap kualitas laporan keuangan daerah.

\section{Pengaruh Pemanfaatan Teknologi Informasi Terhadap Kualitas Laporan Keuangan}

Berdasarkan hasil analisis data yang dilakukan secara parsial menunjukkan bahwa pemanfaaatan teknologi informasi tidak memiliki pengaruh yang signifikan terhadap kualitas laporan keuangan daerah pada OPD Kabupaten Sumenep. Hal ini berarti bahwa baik tidaknya suatu teknologi informasi tidak mempengaruhi terhadap kualitas laporan keuangan, karena semuanya menggunakan teknologi informasi dengan software yang digunakan sudah sesuai standart yang berlaku untuk seluruh pemerintah daerah, sehingga kualitas laporan keuangan tidak tergantung terhadap baik buruknya teknologi informasi. Namun kualitas laporan keuangan tergantung terhadap sumber daya manusia yang mengelola laporan keuangan dan komitmen dari pemerintah setempat. Hasil penelitian ini sejalan dengan penelitian yang dilakukan oleh Dyah Puri Suristiani dan Bestari Dwi Handayani (2015) menyatakan bahwa pemanfaatan teknologi informasi tidak mempunyai pengaruh terhadap kualitas laporan keuangan daerah.

\section{Pengaruh Pengawasan Keuangan Daerah Terhadap Kualitas Laporan Keuangan}

Berdasarkan hasil analisis data yang dilakukan secara parsial menunjukkan bahwa pengawasan keuangan daerah memiliki pengaruh yang signifikan terhadap kualitas laporan keuangan daerah pada OPD Kabupaten Sumenep. Hal ini berarti bahwa pengawasan keuangan daerah pada OPD Kabupaten Sumenep sudah berjalan maksimal. Apabila ditemukannya sebuah kekeliruan atau penyimpangan yang dilakukan oleh oknum yang tidak bertanggung jawab dapat segera dideteksi atau diambil tindakan koreksi. Hasil penelitian ini sejalan dengan penelitian yang dilakukan oleh Kuasa, Nardisyah, dan Syukri Abdullah (2016) menyatakan bahwa pengawasan keuangan daerah mempunyai pengaruh terhadap keandalan laporan keuangan daerah. 
Pengaruh Pengendalian Intern Terhadap Kualitas Laporan Keuangan

Berdasarkan hasil analisis data yang dilakukan secara parsial menunjukkan bahwa pengendalian intern memiliki pengaruh yang signifikan terhadap kualitas laporan keuangan daerah pada OPD Kabupaten Sumenep. Hal ini berarti bahwa pengendalian intern yang dilaksanakan oleh OPD Kabupaten Sumenep sudah berjalan secara optimal dan dilaksanakan secara terus menerus oleh pimpinan dan seluruh pegawai OPD Kabupaten Sumenep. Hasil penelitian ini sejalan dengan penelitian yang dilakukan oleh Dyah Puri Surastiani dan Bestari Dwi Handayani (2015) menyatakan bahwa pengendalian intern mempunyai pengaruh terhadap kualitas laporan keuangan daerah.

\section{CONCLUSIONS}

a. Kompetensi sumber daya manusia tidak memiliki pengaruh signifikan terhadap kualitas laporan keuangan. Pegawai yang tidak berkompeten atau berkompeten tidak mempengaruhi terhadap kualitas laporan keuangan, karena laporan keuangan tersebut dibuat sesuai dengan standart yang dibuat oleh pemerintah dan menggunakan software yang sama.

b. Pemanfaatan teknologi informasi tidak memiliki pengaruh signifikan terhadap kualitas laporan keuangan. Baik tidaknya suatu teknologi informasi tidak mempengaruhi terhadap kualitas laporan keuangan, karena semuanya menggunakan teknologi informasi dengan software yang digunakan sudah sesuai standart yang berlaku untuk seluruh pemerintah daerah.

c. Pengawasan keuangan daerah memiliki pengaruh signifikan terhadap kualitas laporan keuangan. Semakin pengawasan keuangan daerah ditingkatkan maka tidak akan terjadi penyimpangan atau kecurangan dalam pengelolaan laporan keuangan, sehingga laporan keuangan yang dihasilkan berkualitas.

d. Pengendalian intern memiliki pengaruh signifikan terhadap kualitas laporan keuangan, sehingga semakin pengendalian intern dipatuhi dengan baik maka kualitas laporan keuangan juga akan semakin baik.

e. Kompetensi sumber daya manusia, pemanfaatan teknologi informasi, pengawasan keuangan daerah, dan pengendalian intern berpengaruh secara simultan terhadap kualitas laporan keuangan. dengan demikian kompetensi sumber daya manusia, pemanfaatan teknologi informasi, pengawasan keuangan daerah, pengendalian intern semakin baik maka kualitas laporan keuangan semakin baik pula.

Untuk OPD Kabupaten Sumenep diharapkan kedepannya kepada pegawai yang memiliki kompeten dibidang pengelolaan keuangan baik dari pemerintahan atau dari lembaga diluar pemerintah untuk selalu memberikan masukan dan pembaharuan dalam melakukan pengelolaan keuangan dan juga mengenai penerbitan aturan yang menjadi acuan setiap instansi khususnya yang berhubungan dengan keuangan. Untuk peneliti selanjutnya, dapat melengkapi metode survei penelitian ini dengan wawancara dapat menambahkan variabel-variabel lain yang diduga berpengaruh terhadap kualitas laporan keuangan.

\section{REFERENCES}

Agoes, Sukrisno. (2011). Auditing petunjuk Praktis Pemeriksaan Akuntansi oleh kantor Akuntan Publik. Jakarta Selatan: Salemba Empat. 
Gery, Armando. (2013). Pengaruh Sistem pengendalian Intern Pemerintah Dan Pengawasan Keuangan daerah Terhadap Nilai Informasi Laporan keuangan Pemerintah (Studi Empiris Pada Satuan Kerja Perangkat Daerah Di Kota Bukittinggi). Artikel ilmiah

Hariningsih, SP. (2005). Teknologi Informasi.Yogyakarta: Graha Ilmu

Hasibuan \& Malayu, SP. (2011). Manajemen Sumber Daya Manusia. Jakarta : Bumi Aksara.

Herawati, Tuti. (2014). Pengaruh Sistem Pengendalian Intern Terhadap Kualitas Laporan Keuangan (Survei Pada Organisasi Perangkat Daerah Pemda Cianjur. STAR - Study \& Accounting Research. Bandung Business School.

Hery. (2016). Analisis Laporan Keuangan Integrated And Comprehensive Edition. Jakarta: Grasindo

I Gusti, Agung Rai. (2010). Audit Kinerja pada Sektor Publik. Jakarta : Selemba Empat.
Indra, Suyoto Kurniawan. (2016). Determinan Kualitas Laporan Keuangan Pemerintah Daerah. Jurnal ekonomi dan manajemen. Vol. 13, (1)

Jumingan. (2009). Analisis Laporan Keuangan. Jakarta: PT. Bumi Aksara.

Jurnali, Teddy, \& Bambang, Supomo. (2002). Pengaruh Faktor kesesuai tugas teknologi dan pemanfaatan TI terhadap kinerja akuntan publik. Jurnal riset akuntansi Indonesia. Vol 5 No. 2. Hal 214-228

Kuasa, Nadirsyah, \& Syukriy, Abdullah. (2016). Pengaruh Kompetensi Pejabat Pengelola Keuangan, Regulasi Dan Pengawasan Keuangan Daerah Terhadap Kualitas Laporan Keuangan Skpd Di Lingkungan Pemerintah Kabupaten Simeulue. Jurnal Magister Akuntansi Pascasarjana. 